\title{
VARIATIONS IN PERIPHERAL LEVELS OF LH AND TESTOSTERONE IN ADULT MALE RABBITS
}

\author{
B. G. MOOR AND E. V. YOUNGLAI \\ Department of Obstetrics and Gynaecology, Programme in Reproductive Biology, \\ McMaster University, Hamilton, Ontario, Canada L8S 479
}

(Received 11th Fune 1974)

\begin{abstract}
Summary. Seasonal, diurnal and episodic patterns of $\mathrm{LH}$ and testssterone secretion in sexually mature male New Zealand rabbits were studied. Blood samples were obtained from the central ear artery by puncture or through an indwelling catheter, and were assayed for hormones using radioimmunoassay. Testosterone values appeared to be lower in the summer months while LH showed no seasonal cyclicity. There were no significant fluctuations when samples were taken at 10min intervals, but specimens taken every hour for 24 or $36 \mathrm{hr}$ revealed an episodic pattern of release. Peaks of both hormones occurred every 4 to $5 \mathrm{hr}$ in most animals. Testosterone levels ranged from 0.5 to $10 \mathrm{ng} / \mathrm{ml}$ and LH from 15 to $200 \mathrm{ng} / \mathrm{ml}$ of WP360A standard. In general, a rise in LH preceded or coincided with an increase in testosterone. No specific diurnal rhythm could be demonstrated and the patterns appeared to be unrelated to external stimuli.
\end{abstract}

\section{INTRODUCTION}

Pulsatile release of gonadotrophins and testosterone has been established in man (Alford \& co-authors, 1973; Naftolin, Judd \& Yen, 1973), bulls (Katongole, Naftolin \& Short, 1971) and rams (Katongole, Naftolin \& Short, 1974); similar fluctuations of peripheral testosterone levels have been observed in male rats (Bartke, Steele, Musto \& Caldwell, 1973). It was recently reported that in rats (Kinson \& Liu, 1973) and man (Faiman \& Winter, 1971; Bodenheimer, Winter \& Faiman, 1973) a diurnal rhythm of testosterone secretion is apparently superimposed on the pulsatile release patterns.

The male rabbit is a common laboratory experimental model for which there is a paucity of data relating to normal variations in reproductive hormones. Carson \& Amann (1972) have demonstrated a seasonal cycle in the testicular weights of New Zealand rabbits which might reflect changes in testosterone production, but normal secretory, diurnal and seasonal patterns for LH and testosterone have not been systematically studied. These investigations were undertaken to examine these patterns in the mature male rabbit. 


\section{MATERIALS AND METHODS}

Animals

All rabbits used in this study were mature New Zealand White males, weighing 3.8 to $4.9 \mathrm{~kg}$. They were individually housed in stainless steel cages on a $12 \mathrm{hr}$ light/12 $\mathrm{hr}$ dark lighting schedule with water and rabbit pellets freely available.

\section{Sample collection}

Throughout the survey, which was for 1 year, $5 \mathrm{ml}$ blood were taken from each of four rabbits by puncture of the main ear artery at the same time every 2 weeks. The blood was allowed to clot, and the serum was collected and kept frozen at $-20^{\circ} \mathrm{C}$ until assay.

For the short-term observations, samples were taken through an indwelling catheter. At least $18 \mathrm{hr}$ before the start of an experiment, the animals were anaesthetized with about $2 \mathrm{ml}$ sodium pentobarbital $(64.8 \mathrm{mg} / \mathrm{ml}$ : HaverLockhart Laboratories, Calgary) and a Teflon catheter (Angiocath, 20 gauge, $1 \frac{1}{4}$ in.: Deseret Pharmaceutical Co., Sandy, Utah) was inserted into the central ear artery. The catheter was flushed with 50 to $100 \mu \mathrm{l}$ heparin $(1000 \mathrm{units} / \mathrm{ml})$, closed with a plastic luer-lok cap and held in place with adhesive tape.

For sampling, the rabbit was confined in a restraining cage and 1.5 or $2 \mathrm{ml}$ blood was drawn into heparinized syringes and kept on ice until centrifuged; total blood volume loss was $54 \mathrm{ml}$ in the 24- and 36-hr experiments, and 30 to $39 \mathrm{ml}$ when rapid sampling was performed. Plasma was stored at $-20^{\circ} \mathrm{C}$ until assay.

\section{Assay of $\mathrm{LH}$}

The determinations of $\mathrm{LH}$ were performed using a heterologous radioimmunoassay based upon the method of Naftolin \& Corker (1971). A guineapig antiserum raised against rabbit LH (7F GP anti-RLH) was used at a final dilution of $1: 202,500$. Highly purified ovine LH (LER $1056 \mathrm{C} 2,2 \mu \mathrm{g}$ ) was labelled with ${ }^{125} \mathrm{I}$ (NEZ-033H: New England Nuclear Co.) to an approximate sp. act. of $33 \mu \mathrm{Ci} / \mu \mathrm{g}$ following a modified procedure of the method of Greenwood, Hunter \& Glover (1963). Each assay tube contained (1) $100 \mu \mathrm{l}$ of $1 \%$ bovine serum albumin in $0.01 \mathrm{M}$-phosphate-buffered saline, $\mathrm{pH} 7.8$ (BSA-PBS), or $100 \mu \mathrm{l}$ standard (WP360A rabbit LH-FSH-TSH) in $1 \%$ BSA-PBS or $100 \mu \mathrm{l}$ plasma; (2) $50 \mu \mathrm{l}$ antiserum (1:40,500 in $2 \%$ normal guineapig serum-PBS-0.05 M-EDTA); and (3) $50 \mu \mathrm{l}$ tracer (approximately 10,000 $\mathrm{ct} / \mathrm{min}$ ) in $2 \% \mathrm{BSA}-\mathrm{PBS}$, added $24 \mathrm{hr}$ after the antiserum. Incubation was carried out at $5^{\circ} \mathrm{C}$. On the 4 th day, the precipitating second antibody was added and the system was incubated for a further 16 to $24 \mathrm{hr}$. Unbound label was aspirated in the supernatant and the precipitates were counted in a Nuclear Chicago 1185 autogamma spectrometer. The practical sensitivity of the assay was $1.5 \mathrm{ng}$ of the partly purified WP360A rabbit pituitary standard, or about $40 \mathrm{pg}$ of a highly purified rabbit LH preparation (EX130GB), with a standard curve range from 0.8 to $60 \mathrm{ng}$ WP360A. The average intraassay coefficient of variation was $8.7 \%$ for samples assayed in duplicate. 
Dose-response curves generated with available rabbit and ovine pituitary reference preparations and with dilutions of plasma with high LH concentrations are given in Text-fig. 1. There was a significant cross-reaction with ovine thyroid-stimulating hormone (TSH); serum from a rabbit treated with Tapazole, which elevates TSH levels, was also shown to have a high hormone content when analysed in this system. There was little interference from other pituitary glycoproteins. The cross-reaction with ovine prolactin, not shown in the figure, was $0.002 \%$ when compared with the purified rabbit LH.

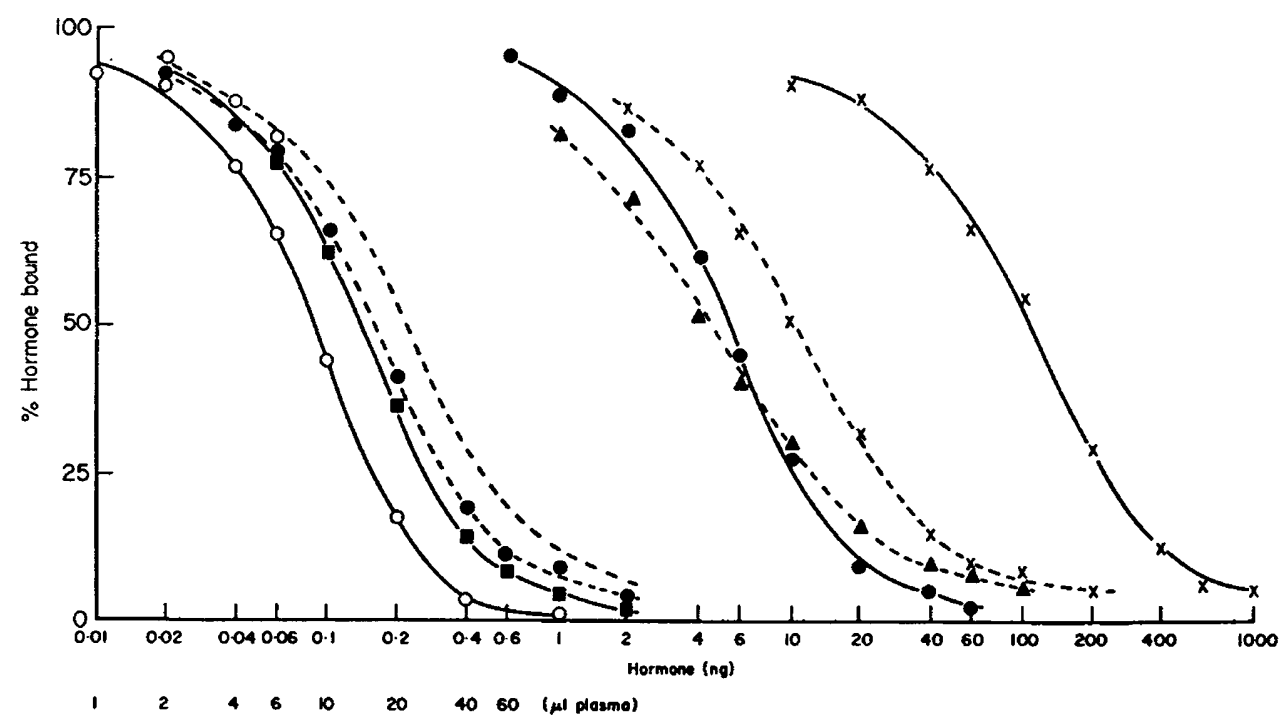

TEXT-FIG. 1. Cross-reactivity of 7F guinea-pig anti-rabbit LH with pituitary glyco-

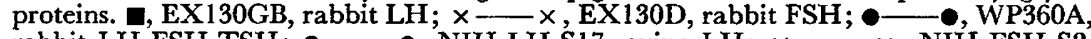
rabbit LH-FSH-TSH; $---\bullet$ NIH-LH-S17, ovine LH; $\times---x$, NIH-FSH-S8, ovine FSH; $O---O$, NIH-TSH-S6, ovine TSH; $\Delta$, NIH-GH-S10, ovine growth hormone; $\mathrm{O}-\mathrm{O}$, rabbit plasma. See 'Acknowledgments' for sources of antiserum and hormones.

\section{Assay of testosterone}

Testosterone antiserum was purchased from Diagnostics Biochem Canada Inc. (London, Ontario) and used as recommended except for the substitution of $0.1 \mathrm{~m}$-PBS, $\mathrm{pH} 6.8$, containing $0.1 \%$ gelatin, as diluent. The assay was sensitive to $50 \mathrm{pg}$, with intra- and inter-assay coefficients of variation of $4.01 \%$ and $9.7 \%$ respectively.

The major cross-reacting steroid in this system was $5 \alpha$-dihydrotestosterone. To assess its contribution to the observations, approximately $800 \mathrm{ct} / \mathrm{min}$ purified $\left[1,2-{ }^{3} \mathrm{H}\right]$ testosterone (NET-187: New England Nuclear) were added to representative sera and the samples were extracted with $2 \times 2.5 \mathrm{ml}$ ether. The extracts were evaporated, dissolved in $0.2 \mathrm{ml}$ eluting solvent $(2,2,4-$ trimethylpentane:benzene:methanol, $90: 5: 5$ by vol.) and chromatographed on Sephadex LH20, using a modification of the method of Bartke et al. (1973). The columns $(0.85 \times 17 \mathrm{~cm})$ contained $1.75 \mathrm{~g}$ Sephadex LH20 equilibrated 
with and packed in benzene:methanol $(85: 15, \mathrm{v} / \mathrm{v})$ and washed with $15 \mathrm{ml}$ eluting solvent. After application of the sample, the first $17.5 \mathrm{ml}$ of effluent were discarded. Dihydrotestosterone was eluted in the next $12 \mathrm{ml}$ and testosterone in a final 15-ml fraction. Both fractions from each column were assayed for 'testosterone' and corrected for recovery. Testosterone constituted about $89 \%$ of the total androgen determined.

\section{RESULTS}

\section{Seasonal levels}

Text-figure 2 shows the mean seasonal levels of $\mathrm{LH}$ and testosterone for four mature male rabbits, from the end of October 1972 to the end of November 1973. There was no seasonal trend for LH. For testosterone, however, a significant difference $(P<0.05$, Student's $t$ test $)$ was found in the mean values of combined data from the periods December 1972 to June 1973 compared to those of July 1973 to November 1973. The testosterone results for October and November of consecutive years also differed significantly $(P<0.001)$.

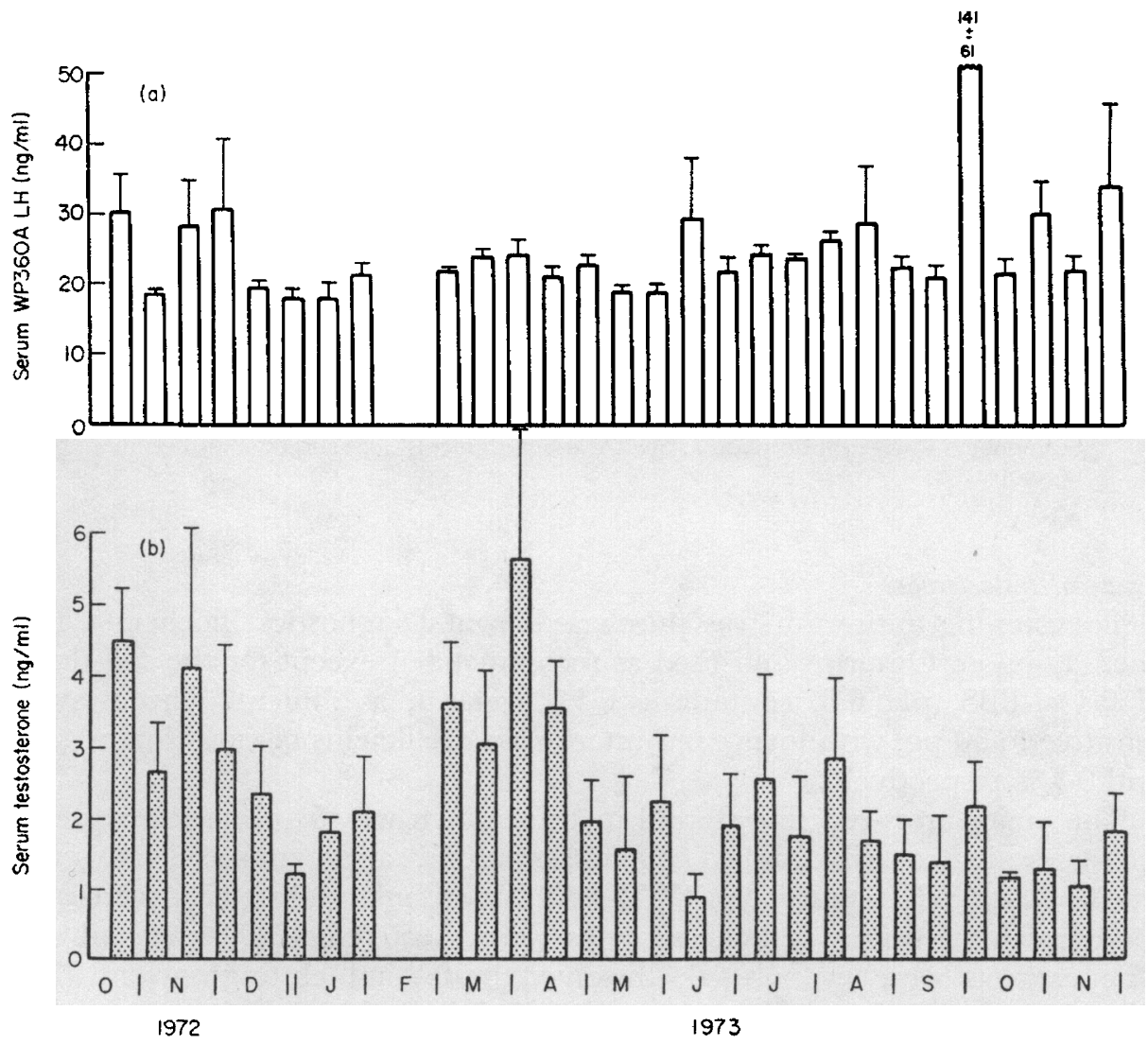

TEXT-FIG. 2. Seasonal levels of peripheral LH (a) and testosterone (b) in four mature male rabbits. Vertical bars represent the Mean \pm S.E.M. 


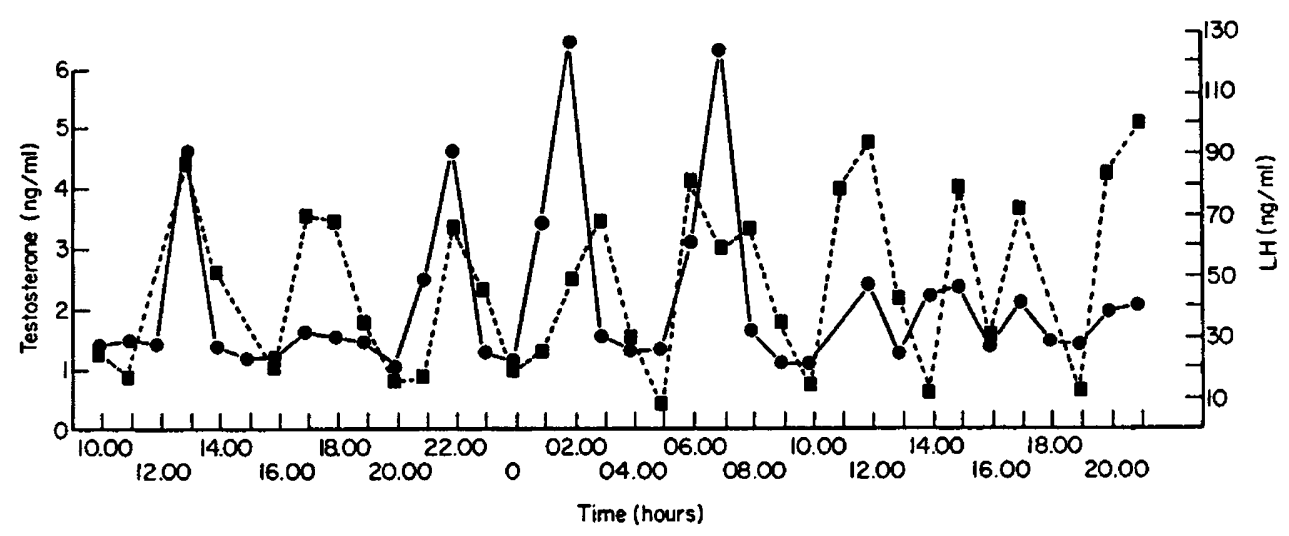

TexT-Fig. 3. The pattern of LH (๑, WP360A) and testosterone ( $\square$ ) concentrations for one rabbit during $36 \mathrm{hr}$ (Eastern Standard Time).

\section{Diurnal variations}

The 36-hr pattern of hormone fluctuations for one rabbit shown in Text-fig. 3 is representative of two $36-\mathrm{hr}$ and six $24-\mathrm{hr}$ experiments on different animals. Circulating levels for both hormones had a striking peak periodicity lasting 4 to $5 \mathrm{hr}$ and, in this animal, there was a good correlation between LH and testosterone peaks, with a rise in testosterone concentration preceded by or coincident with a rise in LH. The pattern in the first $10 \mathrm{hr}$ was not repeated
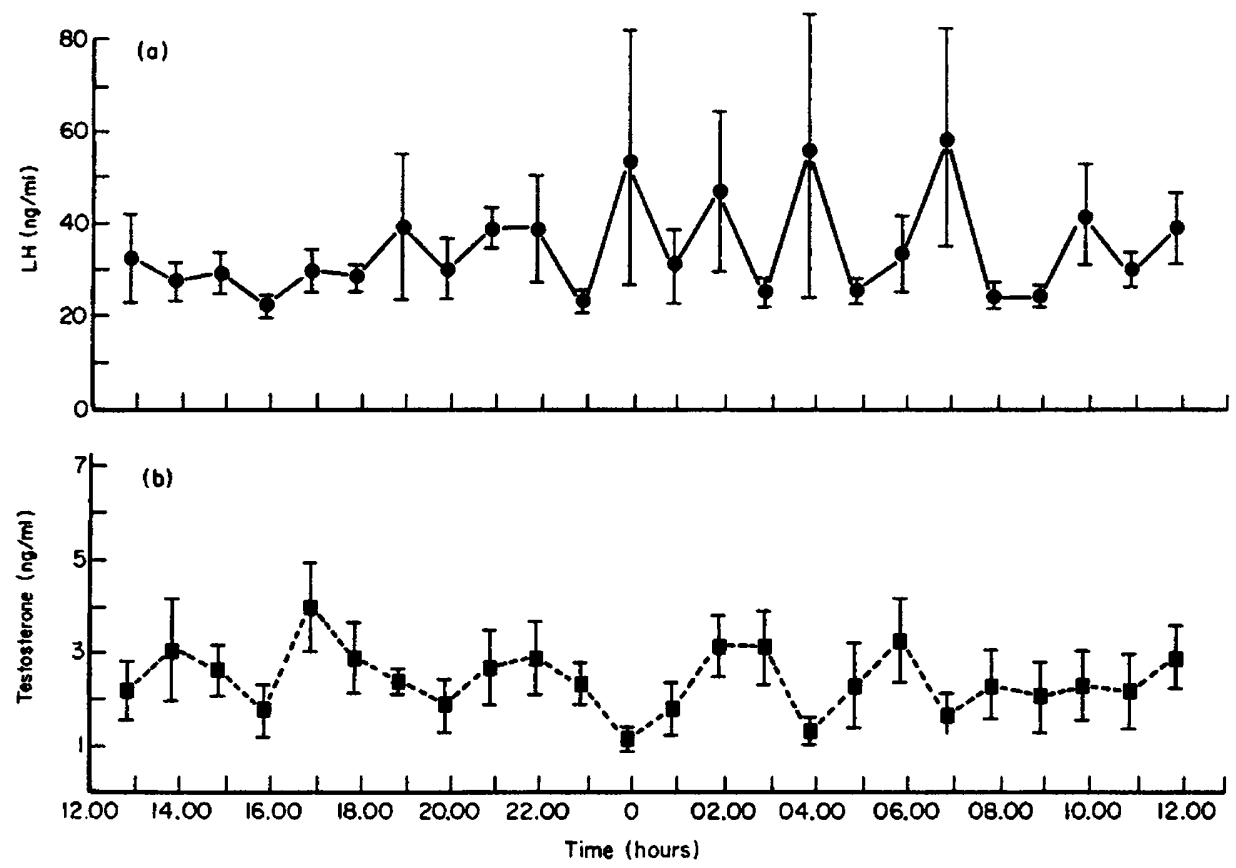

TEXT-FIG. 4. Diurnal variations in (a) LH (WP360A) and (b) testosterone for seven adult New Zealand White male rabbits in Eastern Standard Time. Vertical bars represent the Mean \pm S.E.M. 
the following day, nor did the peaks correspond to external stimuli, such as light, feeding or handling.

The lack of a consistent diurnal rhythm for these New Zealand male rabbits was corroborated by the results shown in Text-fig. 4 for the mean diurnal variations of seven animals. As a consequence of the lack of synchronization of individual rhythms, the standard errors were large and no diurnal pattern emerged. The exceptionally large errors for some $\mathrm{LH}$ points were due primarily to high LH values obtained for one animal.

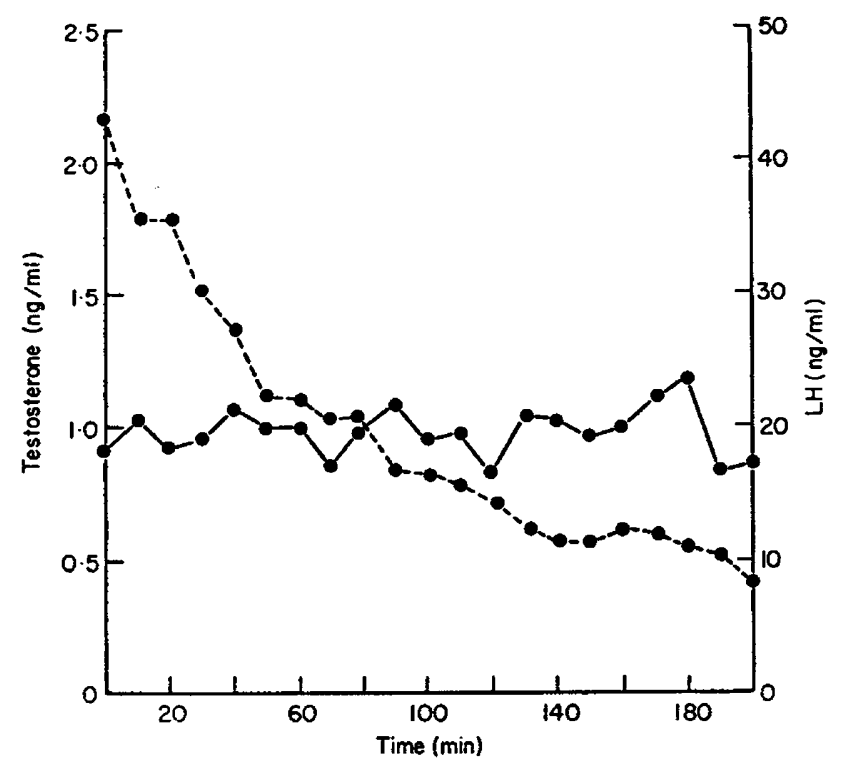

TExT-FIG. 5. Fluctuations of LH (WP360A; - - ) and testosterone (- - - ) observed during rapid sampling every $10 \mathrm{~min}$ in one representative male rabbit.

\section{Rapid sampling}

An attempt to demonstrate low level fluctuations of shorter periodicity superimposed on the rhythms described above was unsuccessful. In six experiments in which samples were taken at 10 -min intervals, no significant rapid oscillations were found (Text-fig. 5). While LH concentrations in these samples may have been too close to the detection limits of the assay to permit a reliable demonstration of minor fluctuations, testosterone exhibited a rate of decay very similar to that of individual peaks in the diurnal studies, with few, if any, basal pulses.

\section{DISCUSSION}

Although there have been several recent reports on LH and testosterone levels in the rabbit, a systematic approach to the secretory patterns of these two hormones has not hitherto been reported. Levels of $\mathrm{LH}$ are low in the male rabbit and correspond to those found by other workers (Dufy-Barbe, Dufy, Faure \& Franchimont, 1972; Scaramuzzi, Blake, Papkoff, Hilliard \& Sawyer, 1972) who have used different heterologous radioimmunoassays. The standard 
used in our experiments (WP360A) was an impure pituitary extract; $1.5 \mathrm{ng}$ corresponds to $40 \mathrm{pg}$ of a highly purified rabbit LH (EX130GB). The antirabbit $\mathrm{LH}$ appeared to be specific, though there was some cross-reaction with serum from rabbits treated with Tapazole; TSH would not be elevated in normal rabbits.

Testosterone concentrations of male rabbits have been measured. Levels found in the present study correspond to those reported by Haltmeyer \& Eik-Nes (1969), Smith \& Hafs (1973) and Rowe, Shenton \& Glover (1973), but the average values were higher than those reported by Saginor \& Horton (1968), who used an isotope-derivative procedure. Chromatography on Sephadex LH20 of some of the extracts of plasma from our experiments before assay indicated that it was primarily testosterone that was being measured.

The annual survey of hormone levels yielded contrasting results for the two hormones. Although no seasonal LH variations were detected, there was a trend towards lower testosterone values in the summer months. This supports the data of Carson \& Amann (1972), who found that testicular weights of New Zealand rabbits were significantly less in the summer, suggesting a concomitant impairment of testicular function. It has been suggested that July to September are the poorest breeding months for domesticated rabbits (Eckstein \& Zuckerman, 1960), but it has not been determined whether this is a reflection of diminished reproductive capacity in the male.

The data obtained from the present studies on diurnal variation confirm the report by Rowe et al. (1973) on testosterone in the rabbit. They also demonstrated that five or six bursts of testosterone secretion occurred every $24 \mathrm{hr}$ but that there was no apparent diurnal rhythm. The fluctuations in LH and testosterone closely resemble those of the bull (Katongole et al., 1971). Pulsatile patterns of release have been demonstrated in man (Alford et al., 1973; Naftolin et al., 1973), but LH peaks occur more frequently and testosterone fluctuations are very rapid. It is difficult to explain why there are 'pulses' of hormone secretion. Although it is known that stress can alter testicular function (Bliss, Frischat \& Samuels, 1972), it was not possible to correlate any of the rapid changes found in the present experiments for either hormone with handling of the animals. From the data shown in Text-fig. 3, it seems that a critical low level of testosterone might be a stimulus for further release. If this is so, it suggests that the feedback mechanisms in the rabbit are much less sophisticated than those in man.

The failure to detect episodic release of the hormones during the rapid sampling experiments on six animals (Text-fig. 5) cannot be explained. Although low level rapid oscillations in LH and testosterone may not exist in the rabbit as they do in man (Nankin \& Troen, 1971; Naftolin et al., 1973), a pulse might have been expected in at least one rabbit (Text-fig. 3) during the course of sampling. Testosterone secretion has been shown to decrease under stress in several species (see Rose, Gordon \& Bernstein, 1972), however, and it is possible that secretion of both hormones may have been influenced by this factor. Relatively stable testosterone levels with a tendency to decline have been noted previously in rabbits used as controls and injected with saline (Smith \& Hafs, 1973). 


\section{ACKNOWLEDGMENTS}

This work was supported by the Medical Research Council of Canada, MT 4192, and E. V. Y. is an M.R.G. Scholar. We are grateful to the following for gifts of hormones or antisera: Dr H. Papkoff (EX 130GB and EX 130D), Dr A. F. Parlow (WP 360A), Dr L. E. Reichert, Jr (LER 1056 C2), Dr R. J. Scaramuzzi ( $7 F$ GP anti-RLH), and the Pituitary Hormone Distribution Program, National Institute of Arthritis and Metabolic Disease, Bethesda, Maryland, U.S.A.

\section{REFERENCES}

Alford, F. P., Baker, H. W. G., Burger, H. G., de Kretser, D. M., Hudson, B., Johns, M. W. Masterson, J. P., Patel, Y. G. \& Rennie, G. G. (1973) Temporal patterns of integrated plasma hormone levels during sleep and wakefulness. II. Follicle-stimulating hormone, luteinizing hormone, testosterone and estradiol. 7. clin. Endocr. Metab. 37, 848-854.

Bartke, A., Steele, R. E., Musto, N. \& Caldwell, B. V. (1973) Fluctuations in plasma testosterone levels in adult male rats and mice. Endocrinology, 92, 1223-1228.

Bliss, E. L., Frischat, A. \& Samuels, L. (1972) Brain and testicular function. Life Sci. 11, $231-238$.

Bodenheimer, S., Winter, J. S. D. \& Faiman, G. (1973) Diurnal rhythms of serum gonadotropins, testosterone, estradiol and cortisol in blind men. F. clin. Endocr. Metab. 37, 472-475.

Carson, W. S. \& Amann, R. P. (1972) The male rabbit. VI. Effects of ejaculation and season on testicular size and function. F. Anim. Sci. 34, 302-309.

Dufy-Barbe, L., Dufy, B., Faure, J. M. A. \& Franchimont, P. (1972) Effets de la castration sur les taux sériques de FSH et LH chez le lapin. C. r. Séanc. Soc. Biol. 166, 1649-1654.

Eckstein, P. \& Zuckerman, S. (1960) The oestrous cycle in the Mammalia. In Marshall's Physiology of Reproduction, 3rd edn, Vol. 1, Part 1, p. 257. Ed. A. S. Parkes. Longmans, London.

Faiman, G. \& Winter, J. S. D. (1971) Diurnal cycles in plasma FSH, testosterone and cortisol in men. 7. clin. Endocr. Metab. 33, 186-192.

Greenwood, F. G., Hunter, W. M. \& Glover, J. S. (1963) The preparation of ${ }^{131}$ I-labelled human growth hormone of high specific activity. Biochem. 7. 89, 114-123.

Haltmeyer, G. C. \& Eik-Nes, K. B. (1969) Plasma levels of testosterone in male rabbits following copulation. 7. Reprod. Fert. 19, 273-277.

Katongole, G. B., Naftolin, F. \& Short, R. V. (1971) Relationship between blood levels of luteinizing hormone and testosterone in bulls, and the effects of sexual stimulation. 7 . Endocr. 50, $457-466$.

Katongole, G. B., Naftolin, F. \& Short, R. V. (1974) Seasonal variations in blood luteinizing hormone and testosterone levels in rams. 7 . Endocr. 60, 101-106.

Kinson, G. A. \& LiU, C. (1973) Diurnal variations in plasma testosterone of the male laboratory rat. Horm. Metab. Res. 5, 233.

Naftolin, F. \& Gorker, C. S. (1971) An ultramicro method for the measurement of luteinizing hormone by radioimmunoassay. In Radioimmunoassay Methods, pp. 641-645. Eds. K. E. Kirkham and W. M. Hunter. Livingstone, Edinburgh.

NAfTolin, F., Judd, H. L. \& YEN, S. S. C. (1973) Pulsatile patterns of gonadotropins and testosterone in man: the effects of clomiphene with and without testosterone. F. clin. Endocr. Metab. 36, 285288.

Nankin, H. R. \& Troen, P. (1971) Repetitive luteinizing hormone elevations in serum of normal men. 7. clin. Endocr. Metab. 33, 558-560.

Rose, R. M., Gordon, T. P. \& Bernstein, I. S. (1972) Plasma testosterone levels in the male rhesus: influences of sexual and social stimuli. Science, $\mathcal{N} . \Upsilon$. 178, 643-645.

Rowe, P. H., Shenton, J. G. \& Glover, T. D. (1973) Testosterone levels in peripheral blood plasma of the rabbit under normal and experimental conditions. Acta endocr., Copenh., Suppl. 177, 124, Abstr.

SAginoR, M. \& HoRTon, R. (1968) Reflex release of gonadotropin and increased plasma testosterone concentration in male rabbits during copulation. Endocrinology, 82, 627-630.

Scaramuzzi, R. J., Blake, G. A., Papkoff, H., Hilliard, J. \& Sawyer, G. H. (1972) Radioimmunoassay of rabbit luteinizing hormone: serum levels during various reproductive states. Endocrinology, 90, 1285-1291.

Sмrтн, O. W. \& Hafs, H. D. (1973) Competitive protein binding and radioimmunoassay for testosterone in bulls and rabbits; blood serum testosterone after injection of LH or prolactin in rabbits. Proc. Soc. exp. Biol. Med. 142, 804-810. 